\title{
The Effectiveness of a programme-based Vocabulary Learning Strategies for Developing English Vocabulary for EFL Female Students at Taif University
}

\author{
Nasrah Mahmoud Ismaiel (Corresponding author) \\ English Language Center, Deanship of Supportive Studies, Taif University, Saudi Arabia \\ E-mail:n.ismaiel@tu.edu.sa \\ AbdulRahman Awadh Al Asmari \\ Applied Linguistics, Foreign Languages Department, Faculty of Arts, Taif University, Saudi Arabia
}

Doi:10.7575/aiac.alls.v.8n.3p.113

Received: $16 / 04 / 2017$

URL: http://dx.doi.org/10.7575/aiac.alls.v.8n.3p.113

Accepted: 19/06/2017

\begin{abstract}
The study of vocabulary can be considered a chief issue which the second language students encounter within the learning of another language especially, for non-English major students. This study aims at assessing the influence of a suggested program for enhancing EFL students' vocabulary and vocabulary learning strategies use. The sample of this study consists of (123) females, it is parted into two sections; the experimental group consists of 55 female students and the control group consists of 68 female students. During the course of the study, learners were randomly chosen and randomly were divided into the experimental and control groups. The aim of the study is twofold: (a) to assess if there exist notable discrepancies between these two groups on the English Language Vocabulary post-test and vocabulary language learning strategies. The study also aims to analyze if there exist important discrepancies in the mean grades of pre and post-test of the English Language Vocabulary test and vocabulary language learning strategies. The research applied will continue for 12 weeks throughout the second semester which includes the proposed program. Students' vocabulary learning strategies were measured by Schmitt's (1997) questionnaire. This questionnaire contains 58 items covering five main strategies that are determination plans, social plans, memory tactics, cognitive plans and metacognitive programs. While the Students` English Language Vocabulary size was measured by English Language vocabulary test that was designed by the researchers. The research accomplished lasted for three months that encompasses the suggested plan. The gathered data demonstrated that there existed statistically important discrepancies between the experimental group and the control group on the post-test, in which the experimental one was more bolded. It also uncovred that there existed statistically important discrepancies among the pre-test and post-test outcomes for the experimental group on the diction examination. Moreover, the grades depicted that there existed statistically notable discrepancies among the experimental group and its counterpart. The data of the present research have notable insinuations for the learners and make an enhanced case for the study of diction and vocabulary.
\end{abstract}

Keywords: Vocabulary learning strategies, Vocabulary test, EFL Saudi female learners, training programme

\section{Introduction}

The study of diction and vocabulary shows one of the main issues that encounter EFL / ESL instructors and students. Many ESL/EFL students have problems in interacting with English language as there is restricted vocabulary. So as to defeat such issues they must apply influential tactics that improve vocabulary accomplishment and retention.

According to our experience in teaching English in Saudi Arabia, the researchers have noticed that during the students' English learning experience in Intermediate and Secondary school, vocabulary was given little regard in the Kingdom's text books. In those books, new words were introduced as an introduction before reading new material, but little followup was done to ensure that the words were really remembered. There is no system or strategies to be sure that the students would ever use the new words again properly or even use them at all.

The researchers believe that the students should be introduced to more vocabulary tactics like Context Clues, Parts of vocabularies- (prefixes, suffixes, and roots), Repetition- Repetition, Personal Thesaurus, Personal Dictionary, Gestures and Conversation. These vocabulary strategies will allow the students to recognize the meanings of words based on their use, will aid students in identifying and determining meanings of unfamiliar words and will help students "own" the new vocabulary. In addition, they help the students to choose the words that should reflect their day-to-day needs. The students need words that will be used in practical situations in addition to the general vocabulary they are being taught now. They need practice in using these practical vocabulary strategies by teaching them these strategies. There is an obvious difference among students who have some vocabulary strategies and learned to think in English and those who have not. Those who have vocabulary strategies are able to speak in English and to use whatever vocabulary they have picked up along the way. However, in order for students to make the jump from being a student who honestly feels 
he cannot communicate in English to one who knows he can, the student must feel that the vocabulary he has been taught is relevant to his needs. Accordingly, the students need basic formal vocabulary, but at the same time that vocabulary must encompass subjects that the learners are probably to apply in their routine lives on a practical basis.

One of the main and significant issues which students will encounter within the process of foreign language instruction is learning words. Vocabulary is known as important to language application in which little diction knowledge of the learners resulted in problems in second language instruction (Asgari \& Mustapha, 2011). According to a number a critics vocabulary is significant to language and in fact is of utmost importance to language EFL/ESL students. Vocabularies are the constitutive parts of a language as they signify objects, actions, opinions without which students are not able to send the desired meaning (Bastanfar, 2010, Kaya \& Charkova, 2014, Lotfi, 2007). By learning new dictions, learners are able to enhance their listening, speaking, reading and writing words and can enhance understanding and creation in L2 (A1 Jarf, 2007). Nassaji (2004) found that ESL "students who had wider vocabulary knowledge made more effective use of certain types of lexical inferencing strategies than their weaker counterparts." (p. 12) August, Carlo, Dressler \& Snow (2005) also agreed that "English language learners who experienced slow vocabulary development were less able to understand texts at the grade 3 level than their English-only peers." These learners were probably to accomplish weakly on evaluations in these parts and were, as showed by Samian \& Tavakoli, (2012) Iranian EFL danger of being diagnosed as learning very weak. The outcomes of Samian \& Tavakoli, (2012) showed that Iranian EFL students applied rote acquisition tactics much frequently than other groups of memory tactics. Moreover, the outcomes indicated that there existed a number of statistically important discrepancy in high and lowintermediate students concerning their rote learning tactic application.

\subsection{Vocabulary learning tactics}

Vocabulary refers to dictions we apply to interact in verbal and written language. Receptive diction alludes to the vocabularies we get by way of reading and listening. Productive diction alludes to the vocabularies we apply to interact by way of writing and speaking (Lehr, Osborn, \& Hiebert, 2004). To interact influentially applying verbal and written language, we should be capable of flexibly applying dictions which we understand (Hanson \& Padua, 2015). The study of word learning tactics is considered a subcategory of language acquisition tactics. Brown and Payne (1994) identify "five steps in the process of learning vocabulary in a foreign language: (a) having sources for encountering new words, (b) getting a clear image, either visual or auditory or both, of the forms of the new words, (c) learning the meaning of the words, (d) making a strong memory connection between the forms and the meanings of the words, (e) using the words" (p. 237).

Cameron (2001) advised an overall specification for word learning tactics which is "actions that learners take to help themselves understand and remember vocabulary." Catalan (2003) suggested a more concrete and precise definition of word learning tactics. She suggested the following explanation:

Knowledge about the strategies used in order to learn vocabulary as well as steps or actions taken by students (a) to find out the meaning of unknown words, (b) to retain them in long-term memory, (c) to recall them at will, and (d) to use them in oral or written mode. This may result in incidental vocabulary acquisition, in increasing the depth of knowledge of the known word by adding new contextually appropriate meanings, and in acquiring totally new words as well (Hu \& Nassaji, 2014, p. 1102).

The study on word learning tactics is almost a new ground of research and study. Researchers' interests in this area started to grow about two decades ago. Vocabulary learning strategies are then language acquisition tactics employed to learn vocabulary in the target language (Cameron, 2001). Cameron believes that learners might not apply word learning tactics autonomously and that they have to be educated to utalize these tactics. Some studies have shown that clear teaching can help improve learners' English language proficiency and particularly diction. According to Lightbown and Spada (1999), adult and more skilled students have the advantage of intentional teaching more than the young students. Some other studies have also indicated that students could enhance the size of their word to a very high level with obvious, de-contextualized reading of the words (Nation, 2001).

\subsection{Classifications of vocabulary learning tactics}

Although the adapting of tactics to learn new vocabulary is an almost novel field of investigation, some categorizations of word acquisition strategies have been proposed. Some of the classifications are quite general in nature while others have the purpose of giving a precise investigation of the different tactics on the foundation of the outcomes of the empirical study.

Ahmed (1989) was the pioneer in the field of studying word learning tactics. He studied 300 Sudanese students of English to realize the micro-tactics they applied and the various tactic samples applied by advanced and by weak students. By the usage of a think-aloud assignment, direct investigation, and an interview to their learning 14 novel dictions, he got 38 micro-tactics that were grouped into six macro-tactics: sources of data, the application of the dictionary, memorization the words, practicing the words, the desired source of data, and note-making. Cluster assessment was then done to create five distinguished categories of learners. Three of the categories were constituted chiefly of good students and two categories were of poor learners. In this way, the strategy patterns used by good and poor learners could be distinguished. 
Sanaoui (1995) organized three studies. The first study was with 50 beginning and advanced ESL learners in 1990. The second considered four case studies of ESL learners in 1992. And the final one was with eight case studies of French as a second language (FSL) learner in 1993. She noted that students in these three studies seemed to use two distinctive approaches to vocabulary learning: a structured and an unstructured approach.

Stoffer (1995) was the first researcher to make an intensive study on diction learning tactics. She prepared a questionnaire of 53 cases created to particularly assess word learning tactics. She created this Vocabulary Learning Strategy Inventory (VOLSI) and the SILL to 707 university learners at the University of Alabama. Stoffer noted that the 53 cases on the VOLSI naturally categorized into nine items which follow: "(1) Strategies involving authentic language use, (2) Strategies involving creative activities, (3) Strategies used for self-motivation, (4) Strategies used to create mental linkages, (5) Memory strategies, (6) Visual/auditory strategies, (7) Strategies involving physical action, ( 8) Strategies used to overcome anxiety, and (9) Strategies used to organize words" (p. 66).

In the same manner, $\mathrm{Gu}$ and Johnson (1996) documented the word learning tactics of 850 second-year Chinese university learners through a diction learning survey, word size exams and skill exams. The survey they designed consisted of a part about learners' creeds about diction learning and a total of 91 diction learning tactics that were categorized into seven sub-categories.

Schmitt (1997) used his own categorization of strategies, using a survey to examine 600 Japanese EFL students consist of junior high, senior high, college learners, and also company employees. His goal was to find whether they used strategies and if so, whether they were useful. He then suggested his own taxonomy of vocabulary learning strategies. He adopted four categories, i.e. Social, Memory, Cognitive, and Metacognitive from Oxford's six language learning strategies (Memory, Cognitive, Compensation, Metacognitive, Affective, and Social) and added a new category, Determination, to his studies. Accordingly, in Schmitt's research, there were 58 strategies grouped into five categories and separated into two dimensions: "discovery of a new word's meaning" and "consolidating a word once it has been encountered". The first of these dimensions involves determination and cultural tactics, and the other also involves cultural tactics, along with memory, cognitive, and metacognitive tactics. The tactic, sociocultural tactics, is involved in both of the two facets as it can be applied influentially in both.

Nation's (2001) study differs from the research mentioned above in that his taxonomy will not originate from any study outcomes but is merely depended on an approach. He categorized it into 3 overall groups, where facets of word understanding have been regarded on by one from resources of word understanding and learning aspects.

Moreover, Lin (2001) investigated the word learning tactics of seven Taiwanese basic learners. A number of study tools were utilized, consisting of classroom watch, written documents, and oral interviews and think-aloud methods. Despite the small instance, 73 word learning tactics were recognized, and those were grouped into three parts: Metacognitive, Cognitive, and Socio-affective. Moreover, every group had its subgroups.

\subsection{Learning vocabulary training}

Researchers have noted that vocabulary has, for the most part, been treated as a "poor relation" as far as language theorists and instructors have been involved (Maiguashca, 1993). Meara (1982) mentioned her displeasure of the manner in which L2 vocabulary is acquired by applied linguists. It was clarified that most learners recognize that vocabulary learning is their biggest hurdle throughout their journey of learning English as a foreign language (p. 100). However, the important role of diction in EFL has been lately known by critics and scholars in the area. So, myriad of sorts of theories, methods, manners and tests have been introduced into the area of learning diction and word (Hatch $\&$ Brown, 1995). It has been recommended that the instruction of vocabulary must not only encompass instructing some dictions but also teaching vocabulary should also help learners learn new strategies in order to help extend their diction knowledge (Hulstjin, 1993). Vocabulary learning strategies could be defined as language learning tactics applied to get new words in the target language. Cameron, (2001) asserts that learners may not utilize word learning tactics by themselves and as a result, they must be educated to apply the tactics.

Research has proven that clear instruction can help develop students' English language skills and especially vocabulary. According to Lightbown and Spada (1999), "older and more advanced learners benefit from intentional instruction more than younger learners. Research also has shown that learners could increase their vocabulary size effectively with explicit, de-contextualized study of vocabulary" (Nation, 2001, p. 4).

Little and Kobayashi (2015) discuss the significance of detailed VLS teaching for both weaker and advanced skilled learners. The greatest advantage from using the various types of acquisition tactics, like word learning tactics, is that using such tactics permits students to have more dominance of their own process of acquistion. This instead results in having more liability for their investigations (Nation, 2001; Scharle \& Szabó, 2000).

A number of scholars recognized different facets of influential vocabulary teaching which are significant for both L1 and L2 learners. For instance, Smith (1983) had a glance on the achievable literature and realized that there existed three fundamental approaches that must be taken as significant for obvious vocabulary teaching that would end to the contribution in word construction. These ideas are: "teaching collocations; knowing a word entails knowledge of the network of associations between that word and other words in the language; and knowing a word means knowing the semantic value of the word" (1993, p. 3).

In the same manner, Johnson \& Steele (1996) suggested a number of "generative vocabulary-building strategies: Vocabulary selection strategies, personal word lists, semantic mapping, imagery, and computer-assisted instruction. 
Peters \& Dixon (1987) also recommended using learning new tags, which include learning concepts; and learning to learn meanings. For effective vocabulary instruction, Burke (2004) also suggested scaffolding instruction; multiple modes and graphic organizers" (p. 3)

On the other hand, Sokmen (1997: 225) is of the persuasion that helps students get how to achieve word on their own which is the manner to advance with acquisition diction, suggesting that it is "not possible for students to learn all the vocabulary they need in the classroom." Cunningsworth (1995: 38) agrees with Sokmen in that he believes helping students improves their own diction acquisition tactics and is "a powerful approach" that can be founded on a comprehension of the manners of diction, the contribution of good dictionary practices and also the consideration of influential learning methods.

Although the amount of empirical study on the achievement of diction is enhancing (e. g., Haastrup, 1991; Mondria \& Witde- Boer, 1991; Wang, Thomas, Inzana, \& Primicerio, 1993), there exists no contract on issues like the method by which word learning happens, the relevance of the application of context for getting diction, and the amount to which learners actually improves a number of specific tactics by which to acquire diction when they assess language (Lawson \& Hogben, 1996). According to Nation (200; 80), acquiring diction is an accumulative action and that vocabulary must be intentionally taught, achieved, and reused. Additionally, Nation maintained that because learners need to discover the words in a variety of fertile contexts, often requiring them to encounter the new words up to sixteen times and because learners more often remember new words when they have employed them in different ways, variety in words and contexts is crucial for teaching vocabulary. He added that learners tend to forget words within the first twenty-four hours after having encountered them, so follow up is imperative with vocabulary lessons, including homework, that recycle the words.

\section{Jitendra, Edwards, Sacks \& Jacobson (2004) summarized:}

Published research on vocabulary instruction involving students with learning disabilities. Nineteen vocabulary studies that comprised 27 investigations were located. Study interventions gleaned from the review included keyword or mnemonic approaches, cognitive strategy instruction (e.g., semantic features analysis), direct instruction, constant time delay, activity-based methods, and computer-assisted instruction (CAI). While findings for the keyword, cognitive strategy, direct instruction, constant time delay, and activity-based procedures were generally effective in enhancing vocabulary performance for students with learning 11 disabilities, results for CAI were mixed. The studies are discussed with regard to study characteristics (e.g., intervention intensity, instructional arrangement) (p. 299).

Learners are required to face word in various contexts so as to remember it and to design a comprehension of the amount of the application of a given diction. Nation (2001:80) believes that dictions are to be present in various places as contexts-of-use are related to various cognitive acts within language acquisition. Nation asserts that the student should be able to know the diction as it is verbalized, recognizing that the vocabulary is created in various morphological sections and be able to associate such sections to its signification, realize the meaning of the diction, and also realize what the diction signifies in the specific context in which it been used, and create the diction to assert its suitable meaning and effectively apply the word in an real caluse.

\subsection{The Statement of the Problem}

The acquisition of a foreign language includes the achievement of four chief practices; speaking, writing, listening and reading, which results in an influential interaction. One notable element is the range of diction everybody possesses as the word constitutes the greatest section of the signification of any language (McCarthy, 1988). Word, nevertheless, is the greatest issue for most EFL/ESL students (Meara, 1995; Milton, 2009; Nation, 2001; Schmitt, 2000). In one very real sense, word learning is recently getting attention in second/foreign language teaching and investigation. But can be regarded as a constant problem how students achieve word influentially and properly or how it can best be instructed.

Another reason for testing this problem is that word is usually rendered little concentration in the plans in Asian universities (Fan, 2003, Somsai \& Intaraprasert, 2011, Akkakoson 2012) and this includes a crucial situation in Saudi Arabia. And a situation having a little emphasis on teaching vocabulary in the university curriculum even hardly exists especially for the EFL students is the same, if not worse, in the middle schools.

On the whole, the focus on English instruction in the college is on the four language talents. Word instruction in many courses is mainly haphazard (Fan, 2003; Catalan, 2003). According to Catalan "This means that when a particular word or phrase appears difficult for the students, they are told the definitions - a matter of translation. More often, however, finding out about new vocabulary items is left to the discretion of the students, and they are encouraged to turn to dictionaries to look up the meanings of words" (Catalan, 2003, p. 12). Catalan goes on to say that diction acquisition is, as a result, largely for a specific aim and very relied on the attempts of the instructors and learners. This informal theory to word acquisition may result in an overall insufficiency in word knowledge in Asian university learners. As Fan (2003) asserts this is repeatedly asserted by the scholars and instructors as one of the elements in the unsatisfactory practice of learners in their tests. He maintains that the insufficiency in word knowledge can interrupt learners' skill improvement and influence their performances in tests.

A third reason for addressing this issue in this research is that there exist numerous dictions on which the instructors may not capable of spending time in the class time restricts. So, if learners have a number of diction learning tactics via 
practicing, they may deal with such vocabularies on their own and as a consequence have access to a great range of target language dictions. Another incentive for doing this research is because there are only a limited number of empirical studies that address the issue of vocabulary language learning for EFL learners in native Arabic speakers of English as a foreign language, especially in Saudi Arabia.

\subsection{This study addresses the following hypotheses}

1. There exist significant discrepancies between the experimental group grades and the control group on the post-test of English Language diction exam and diction learning tactics. Namely, the experimental group learners had a better grade than the control group.

2. There exist significant discrepancies between the mean grades of the pre and post-test of the English Language diction test and diction learning tactics. The experimental group grades are better than in the post-test.

3. There exist no notable discrepancies between the mean grades of the post-test and follow up of the English Language diction test and diction learning tactics.

\subsection{Significance of the study}

The purpose of the present research is to develop learners' diction learning. The researchers believe that this kind of vocabulary training programme can have great benefits for the learners. It makes a kind of awareness for the EFL learners, EFL instructors and curriculum designers. It makes instructors more sensitive to their roles in instructing EFL diction. It also contributes the learners to enhance diction tactics and methods to get more motivated and autonomous students.

\subsection{The purposes of the study}

1. To investigate the contribution of EFL diction acquisition tactics practice to learners' diction increase and enhancement.

\section{Method}

\subsection{Pilot study}

Seventy learners were haphazardly selected from the EFL preparatory non -English chief learners, first level, for the pilot research to specify the range of time needed to complete the questionnaires and to know the validity and reliability of the instruments. All of them are Saudis. Their age ranges from 18 to 22 years old, $\mathrm{M}=18.96, \mathrm{Sd}=0.77$. All of them are Saudis.

\subsection{Participants}

In the present study, one hundred- twenty-three EFL female preparatory non -English major Saudi students took part in the study. They study English for 12 hours per week. The learners are all Saudi and are all native students of Arabic. They were all beginners level. The participants were divided into two groups; experimental group consists of 55 female students and the control group consists of 68 students. All of these learners had 6 years of EFL teaching in scores 6-12. Their ages ranged from 18 to $24(\mathrm{M}=18.7071, \mathrm{SD}=0.817)$. Prior to their admission to Taif University. The experimental group was rendered the diction plan, while the control group was not given the plan. Before teaching, learners in both the experimental group and the control group were pretested by taking the same vocabulary test and learning vocabulary strategies questionnaire.

\subsection{Instruments}

\section{A. Vocabulary test}

This test contains 52 items that was prepared by the researchers. The items were multiple choices. Scoring was objective; one point for each correct answer. Scores ranged from 0 to 40 . For the vocabulary test, participants took pretest to identify whether or not they had any existing knowledge about the vocabulary that was the focus for the particular units.

To estimate the discrimination index, it was determined to take a highest group and a lowest group from the pilot sample study. The highest group was $27 \%$ of (16 students out of 57) and the lowest group was $27 \%$ of the cases of the students (16 students out of 57) according to their total scores or marks in the listening test. Then the discrimination index was estimated or calculated via the percentage of learners who were able to reply rightly on each question in the highest group minus or besides the learners who were able to respond correctly on each question in the lowest group as it was mentioned in (Alaam, 2011, 114-117).

Table 1. difficulty, variance and discrimination indices for vocabulary test

\begin{tabular}{llllllll}
\hline $\begin{array}{l}\text { No. of } \\
\text { items }\end{array}$ & $\begin{array}{l}\text { Difficulty } \\
\text { index }\end{array}$ & $\begin{array}{l}\text { Discrimination } \\
\text { index }\end{array}$ & $\begin{array}{l}\text { Variance } \\
\text { index }\end{array}$ & $\begin{array}{l}\text { No. of } \\
\text { items }\end{array}$ & $\begin{array}{l}\text { Difficulty } \\
\text { index }\end{array}$ & $\begin{array}{l}\text { Discrimination } \\
\text { indexes }\end{array}$ & $\begin{array}{l}\text { Variance } \\
\text { index }\end{array}$ \\
\hline 1 & 0.44 & 0.22 & 0.14 & 28 & 0.66 & 0.22 & 0.07 \\
\hline 2 & 0.84 & 0.13 & 2.08 & 29 & 0.48 & 0.25 & 0.13 \\
\hline 3 & 0.48 & 0.25 & 0.13 & 30 & 0.68 & 0.22 & 0.07 \\
\hline 4 & 0.74 & 0.23 & 0.08 & 31 & 0.42 & 0.24 & 0.14 \\
\hline 5 & 0.64 & 0.19 & 0.05 & 32 & 0.70 & 0.21 & 0.06 \\
\hline 6 & 0.64 & 0.19 & 0.05 & 33 & 0.80 & 0.16 & 0.03 \\
\hline
\end{tabular}




\begin{tabular}{|c|c|c|c|c|c|c|c|}
\hline 7 & 0.70 & 0.21 & 0.06 & 34 & 0.82 & 0.15 & 0.03 \\
\hline 8 & 0.80 & 0.16 & 0.03 & 35 & 0.90 & 0.09 & 0.09 \\
\hline 9 & 0.42 & 0.24 & 0.14 & 36 & 0.32 & 0.22 & 0.15 \\
\hline 10 & 0.50 & 0.25 & 0.13 & 37 & 0.54 & 0.25 & 0.12 \\
\hline 11 & 0.18 & 0.15 & 0.12 & 38 & 0.72 & 0.20 & 0.06 \\
\hline 12 & 0.22 & 0.17 & 0.13 & 39 & 0.48 & 0.25 & 0.13 \\
\hline 13 & 0.40 & 0.24 & 0.14 & 40 & 0.79 & 0.12 & 0.03 \\
\hline 14 & 0.62 & 0.24 & 0.09 & 41 & 0.62 & 0.24 & 0.09 \\
\hline 15 & 0.78 & 0.17 & 0.04 & 42 & 0.64 & 0.23 & 0.08 \\
\hline 16 & 0.50 & 0.25 & 0.13 & 43 & 0.48 & 0.25 & 0.13 \\
\hline 17 & 0.64 & 0.25 & 0.12 & 44 & 0.48 & 0.25 & 0.13 \\
\hline 18 & 0.70 & 0.21 & 0.06 & 45 & 0.38 & 0.24 & 0.14 \\
\hline 19 & 0.48 & 0.25 & 0.13 & 46 & 0.26 & 0.19 & 0.14 \\
\hline 20 & 0.72 & 0.20 & 0.06 & 47 & 0.62 & 0.24 & 0.09 \\
\hline 21 & 0.56 & 0.25 & 0.11 & 48 & 0.54 & 0.25 & 0.012 \\
\hline 22 & 0.66 & 0.22 & 0.07 & 49 & 0.32 & 0.22 & 0.15 \\
\hline 23 & 0.62 & 0.24 & 0.09 & 50 & 0.64 & 0.23 & 0.08 \\
\hline 24 & 0.36 & 0.23 & 0.15 & 51 & 0.24 & 0.18 & 0.14 \\
\hline 25 & 0.68 & 0.22 & 0.07 & 52 & 0.18 & 0.15 & 0.12 \\
\hline 26 & 0.78 & 0.17 & 0.04 & & & & \\
\hline 27 & 0.62 & 0.24 & 0.09 & & & & \\
\hline
\end{tabular}

The proper amount for simplicity index is from 0.15 to 0.85 (Alaam, 2011, 114). As indicated in table (1) all the investigations during this amount. While according to the discrepancy index, twelve had been omitted (questions $2,5,6,8,15,20,26,33,34,35,38 \& 40)$. As their discrepancy demonstrations were under 0.2 , they were not improved cases (Alaam, 2011, 116). So the diction exam got 40 cases instead of 52.40 grades for the whole exam, one grade for every true reply and the false respond became zero. So the scores on the exam are from 0 to 40 .

B. Vocabulary learning strategies questionnaire (VLS)

Schmitt‘s VLS taxonomy (1997) was applied in the present research. It involves 58 various tactics grouped into two areas: tactics applied to understand the signification of the unknown dictions (discovery tactics), and tactics applied to boost the signification of the novel diction (boost tactics). Schmitt's taxonomy encompasses usually applied VLS that have their place in one of the below six groups:

1) Discovery-determination (e.g. analyzing parts of speech, checking for L1 cognates, guessing from context, and use of bilingual or monolingual dictionary), 2) Discovery-social (e.g. asking the L2 teacher for an L1 translation, asking classmates for meaning, and discovering meaning through a group work activity), 3) Consolidation-social (e.g. study and practice word meaning in a group and interaction with native speakers), 4) Consolidation-memory (e.g. study word with a pictorial representation of its meaning, using semantic maps, imaging word form, using keyword mnemonics, and connecting words to a personal experience), (5) Consolidation-cognitive (e.g. note-taking, verbal repetition, written repetition, word lists, flash cards, and keeping a vocabulary journal or notebook, make sentences, ), and 6) Consolidationmetacognitive (e.g. testing oneself with word tests, use of target language media, using spaced word practice and continuing to study a word over time) (p. 20).

Schmitt's VLS taxonomy is grouped into two areas in relation to Nation's (1990) recommendations: uncovering tactics (cases 1 to 14) that are tactics applied to find out the specification of an unfamiliar diction, and boost tactics (cases 15 to 58) that are cases applied to boost (i.e. learn) the signification of a formerly unfamiliar diction. Discovery tactics are moreover subcategorized into determination tactics (cases 1 to 9) and social tactics (cases 10 to 14). Consolidation tactics, on the other hand, are subcategorized into cultural (cases 15 to 17), memory (cases 18 to 44), cognitive (cases 45 to 53), and metacognitive tactics (cases 54 to 58). Learners had to reply to if they apply every tactic A (never), B (infrequently), C (sometimes), D (often) and E (frequently) applying a 5-point Likert method. Every reply was worth between one grade (A) and five grades (E).

Based on Alpha reliability item total correlations, three items were deleted $(14,57 \& 58)$ and then the questionnaire became 55 items instead of 58. Subscale 1, determination strategies includes 9 items (items 1 through 9), subscale 2 includes 4 items (social strategies) (items 10 through 13), subscale 3 ,( social) includes 3 items (items 14 through 16), subscale 4, (memory), includes 27 items (items 17 through 43), subscale 5, cognitive, includes 9 items, (items 44 through 52), and subscale 6, (metacognitive strategies), includes 3 items (items 53 through 55).

\subsection{Vocabulary learning strategies questionnaire (VLS) validly and reliability in the current study}

The rectified item-total correlation rated from 0.39 to $0.70(\mathrm{p}<0.01)$, showing enough case prestige. The rectified itemSubscale 1 (Uncovering-determination) correlation rated from 0.33 to $0.71(\mathrm{p}<0.01)$. For Subscale 2 (Uncoveringsocial) the correlation rated from 0.43 to $0.85(\mathrm{p}<0.01)$. For Subscale 3 (Boost-social) the correlation rated from 0.66 to $0.73(\mathrm{p}<0.01)$. For Subscale 4 (Boost-memory) the correlation rated from 0.34 to $0.86(\mathrm{p}<0.01)$. For Subscale 5 
(Boost-cognitive) the correlation ranged from 0.39 to $0.69(\mathrm{p}<0.01)$. For Subscale 6 (Consolidation-metacognitive) the correlation ranged from 0.62 to $0.76(\mathrm{p}<0.01)$. The correlation between factors ranged from 0.41 to 0.63 , while the correlation among factors and total score ranged from 0.32 to 0.93 . ( $p<0.05$ to $p<0.01$ ). And this indicates that there are positive correlations among vocabulary strategies for six subscales and indicating that subscales of the vocabulary strategies questionnaire display high internal consistency in measuring the students' vocabulary strategies.

The fundamental integration was improved for the total survey $(\alpha=0.88$, split half $=92)$, and for the subscale $1(\alpha=0.69$, split half $=78)$, subscale $2(\alpha=0.61$, split half $=66)$, subscale $3(\alpha=0.56$, split half $=58)$, subscale $4(\alpha=0.78$, split half $=88)$, subscale $5(\alpha=0.69$, split half $=78)$ and for subscale $6(\alpha=0.79$, split half $=81)$. The mean total score was 192.41 (S.D. $=18.83)$. The mean for subscale 1 was 31.87 (S.D. $=4.46)$, for subscale 2 was 12.08 (S.D. $=1.60)$, for subscale 3 was $11.11($ S.D. $=1.87)$ and for subscale 4 was $39.44($ S.D. $=10.01)$, for subscale 5 was $32.90($ S.D. $=4.68)$ and for subscale 6 was $11.00($ S.D. $=2.19)$.

\subsection{Vocabulary language learning Training program}

The English course of 101 was taught for 14 weeks. Students in the experimental and control groups studied the same textbook: English 101:(4th Edition), by Monash College Pty Ltd (2015). The textbook consists of 7 units + a unit revision. The units covered in class were: Nice to meet you, personal information, People and family, personal possessions, Daily routines, leisure time, mid-semester review. The training period started in the beginning of the first semester 2016 /2017. The plan encompassed 20 classes; two courses each week and it continued for three months; two months for applied the sessions and then the follow up came after one month. Tools and aids that were used in the program are vocabulary lists, flash cards, and diction notebooks to read dictions and sentence completions, give antonym or synonym, make a connection to another word, use the word in a sentence, give your definition of the word, act it out. The vocabulary programs tried to offer a variety of tools so all types of learners can benefit.

The program assessed via the pre-tests and post-tests, via the comparison among the experimental and control individuals grades and also via the follow up in developing English language vocabulary after one month from stopping the program. The programme was based Schmitt's VLS taxonomy (1997) diction acquisition tactics. Schmitt's VLS taxonomy is grouped into two areas in relation to Nation's (1990) recommendations: uncovering tactics (cases 1 to 14) that are tactics applied to find out the specification of an unfamiliar diction, and boost tactics (cases 15 to 58) that are cases applied to boost (i.e. learn) the signification of a formerly unfamiliar diction. The instrument is reproduced Appendix B. The researcher tried to familiarize and make the students cognizant of the help of these tactics to their diction size during the application of the programme and asked them to apply these tactics in their word acquisition.

\section{Results}

Table 2. T-test for the discrepancies between control group and experimental group grades on the pre- test of diction learning tactics survey, its factors, and word examination

\begin{tabular}{|c|c|c|c|c|c|c|c|}
\hline $\begin{array}{c}\text { Vocabulary learning strategies } \\
\text { questionnaire subscales and } \\
\text { Vocabulary test score }\end{array}$ & Group & $\mathrm{N}$ & Mean & Std. Deviation & $\mathrm{df}$ & $\mathrm{T}$ & Sig \\
\hline \multirow[b]{2}{*}{ Determination strategies } & Control & 68 & 31.662 & 4.778 & 121 & 0.288 & 0.820 \\
\hline & Experimental & 55 & 31.855 & 4.519 & & & \\
\hline \multirow[b]{2}{*}{ Social strategies } & Control & 68 & 15.279 & 2.509 & 121 & 1.347 & 0.181 \\
\hline & Experimental & 55 & 15.909 & 2.662 & & & \\
\hline \multirow[b]{2}{*}{ Consolidation Strategies } & Control & 68 & 11.177 & 2.073 & 121 & 0.055 & 0.955 \\
\hline & Experimental & 55 & 11.200 & 2.578 & & & \\
\hline \multirow[b]{2}{*}{ Memory strategies } & Control & 68 & 100.912 & 10.654 & 121 & 0.643 & 0.522 \\
\hline & Experimental & 55 & 99.564 & 12.614 & & & \\
\hline \multirow[b]{2}{*}{ Cognitive strategies } & Control & 68 & 34.588 & 4.194 & 121 & 1.124 & 0.263 \\
\hline & Experimental & 55 & 33.655 & 5.016 & & & \\
\hline \multirow[b]{2}{*}{ Metacognitive strategies } & Control & 68 & 10.588 & 2.420 & 121 & 0.609 & 0.544 \\
\hline & Experimental & 55 & 10.277 & 3.319 & & & \\
\hline \multirow[b]{2}{*}{ Total } & Control & 68 & 204.235 & 20.398 & 121 & 0.022 & 0.983 \\
\hline & Experimental & 55 & 204.146 & 24.855 & & & \\
\hline \multirow[b]{2}{*}{ Vocabulary test score } & Control & 68 & 21.500 & 6.085 & 121 & 0.941 & 0.399 \\
\hline & Experimental & 55 & 20.418 & 6.646 & & & \\
\hline
\end{tabular}

Table (2) reflects that there did not exist notable discrepancies between the control and experimental groups on the pretest of the vocabulary learning strategies, its factors, vocabulary test score and age. 
Table 3. T-test for the discrepancies between control and experimental groups of the post-test on the vocabulary strategies questionnaire and its factors and vocabulary test

\begin{tabular}{|c|c|c|c|c|c|c|c|c|}
\hline $\begin{array}{c}\text { Vocabulary learning strategies } \\
\text { questionnaire subscales and } \\
\text { Vocabulary test score }\end{array}$ & Group & $\mathrm{N}$ & Mean & $\begin{array}{c}\text { Std. } \\
\text { Deviation }\end{array}$ & df & $\mathrm{T}$ & Sig & $\eta^{2}$ \\
\hline \multirow[t]{2}{*}{ Determination strategies } & Control & 68 & 31.765 & 4.169 & 121 & 2.880 & 0.001 & 0.064 \\
\hline & experimental & 55 & 34.055 & 4.637 & & & & \\
\hline \multirow[t]{2}{*}{ Social strategies } & Control & 68 & 15.529 & 2.353 & 121 & 4.366 & 0.001 & 0.136 \\
\hline & experimental & 55 & 17.818 & 3.443 & & & & \\
\hline \multirow[t]{2}{*}{ Consolidation strategies } & Control & 68 & 11.118 & 1.833 & 121 & 3.818 & 0.001 & 0.108 \\
\hline & experimental & 55 & 12.691 & 2.721 & & & & \\
\hline \multirow[t]{2}{*}{ Memory strategies } & Control & 68 & 99.588 & 11.583 & 121 & 3.556 & 0.001 & 0.095 \\
\hline & experimental & 55 & 106.836 & 10.801 & & & & \\
\hline \multirow[t]{2}{*}{ Cognitive strategies } & Control & 68 & 33.294 & 5.206 & 121 & 3.771 & 0.001 & 0.105 \\
\hline & experimental & 55 & 37.036 & 5.786 & & & & \\
\hline \multirow[t]{2}{*}{ Metacognitive strategies } & Control & 68 & 10.544 & 2.599 & 121 & 3.800 & 0.001 & 0.107 \\
\hline & experimental & 55 & 12.636 & 3.503 & & & & \\
\hline \multirow[t]{2}{*}{ Totals } & Control & 68 & 201.838 & 22.437 & 121 & 4.700 & 0.001 & 0.154 \\
\hline & experimental & 55 & 220.836 & 22.105 & & & & \\
\hline \multirow[t]{2}{*}{ Vocabulary test score } & Control & 68 & 25.235 & 6.430 & 121 & 4.609 & 0.001 & 0.149 \\
\hline & experimental & 55 & 30.189 & 5.214 & & & & \\
\hline
\end{tabular}

Table (3) has indicated that there are significant differences between the control group $(\mathrm{M}=201.838, \mathrm{SD}=22.437)$ and the experimental group $(\mathrm{M}=220.836, \mathrm{SD}=22.105) t(121)=4.700, p=0.001, \boldsymbol{\eta}^{2}=0.154$. on the vocabulary questionnaire strategies and its factors, for the experimental group. It also has shown that there are significant differences between the control $(\mathrm{M}=25.235, \mathrm{SD}=6.430)$ and experimental group $(\mathrm{M}=30.189, \mathrm{SD}=5.214), t(121)=$ 4.609, $p=0.001, \eta^{2}=0.149$ on the vocabulary test score, in favor of the experimental group. They took the same vocabulary test. The table shows that the value of eta square is high and This means that the training program has a positive strong effect.

Table 4. T-test for the differences between the mean scores of the pre and post-test of the vocabulary learning strategies and the English language vocabulary test for the experimental group

\begin{tabular}{llllll}
\hline Vocabulary learning strategies & Paired Differences & T & df & Sig. (2-tailed)
\end{tabular}
questionnaire subscales and $\quad$ Mean Std. Deviation
Vocabulary test score

\begin{tabular}{cccccccc}
\hline Determination strategies & 2.200 & 5.244 & 3.111 & 54 & 0.003 & 0.152 \\
\hline Social strategies & 1.909 & 5.045 & 2.806 & 54 & 0.007 & 0.127 \\
\hline Consolidation strategies & 1.491 & 4.141 & 2.670 & 54 & 0.010 & 0.117 \\
\hline Memory strategies & 7.273 & 17.659 & 3.054 & 54 & 0.004 & 0.147 \\
\hline Cognitive strategies & 3.382 & 7.866 & 3.189 & 54 & 0.002 & 0.158 \\
\hline Metacognitive strategies & 2.364 & 5.658 & 3.098 & 54 & 0.003 & 0.151 \\
\hline $\begin{array}{c}\text { Total learning Vocabulary } \\
\text { strategies }\end{array}$ & 16.690 & 37.339 & 3.315 & 54 & 0.002 & 0.169 \\
\hline Vocabulary test score & 9.764 & 8.955 & 8.086 & 54 & 0.000 & 0.548 \\
\hline
\end{tabular}

It is seen from the table that there exist important discrepancies between the total mean grades of the pre- $(M=204.146$, $\mathrm{SD}=24.850$ and post-test $(\mathrm{M}=220.836, \mathrm{SD}=22.105),)=0.000, t=54, \boldsymbol{\eta}^{2}=169$ of the English language learning vocabulary strategies in favor of the post-test. For the vocabulary test, it is seen that there are significant differences between the mean scores of the pre- $(\mathrm{M}=20.418, \mathrm{SD}=6.646)$ and post-test $(\mathrm{M}=30.182, \mathrm{SD}=5.214), \mathrm{p}=0.000, \mathrm{t}=54$, $\boldsymbol{\eta}^{2}=548$ in favor of the post- test. This means that the training programme has a positive strong effect on the students' writing skill and writing achievement. 
Table 5. the differences between the mean scores of the post-test and follow up of the vocabulary learning strategies and English language vocabulary test

\begin{tabular}{|c|c|c|c|c|c|c|c|c|}
\hline Variables & & Mean & SD & $\begin{array}{c}\text { Paired } \\
\text { Differences } \\
\text { Mean }\end{array}$ & $\begin{array}{c}\text { Std. } \\
\text { Deviation }\end{array}$ & $\mathrm{T}$ & $\mathrm{df}$ & $\begin{array}{l}\text { Sig. (2- } \\
\text { tailed) }\end{array}$ \\
\hline \multirow{2}{*}{$\begin{array}{l}\text { Vocabulary } \\
\text { Strategies }\end{array}$} & Post-test & 220.836 & 22.105 & & & & & \\
\hline & Flow up & 220.782 & 20.193 & 0.054 & 6.319 & .064 & 54 & .949 \\
\hline \multirow[b]{2}{*}{ Vocabulary test } & Post-test & 30.182 & 5.214 & -.2182 & 2.299 & -.704 & 54 & .485 \\
\hline & Flow up & 30.400 & 4.491 & & & & & \\
\hline
\end{tabular}

Table (5) indicates that there exist no discrepancies between post and follow exams. The research uncovers that there exist no statistically notable discrepancies between the first post-test and the second post-test that was accomplished a month after the first post-test on the diction exam. And this demonstrates that the influence of the diction practicing plan kept on and has a good benefit to EFL students.

\section{Discussion}

The chief objective of the current article was to assess the influence of a training plan according to diction learning tactics to develop the English language vocabularies of college learners. The outcomes of this research depicted that obvious word teaching through the program had a positive effect on the vocabulary acquisition of EFL students and had a good influence also on the general practice in the course. The outcomes of the present research proved that there exist statistically notable discrepancies between the mean grades of the experimental group in every of the pre- and post-test accomplishment and the control one in favor of the experimental one. The outcomes of the current research demonstrated that diction learning tactics training contributed to improve learners` English word, because word tasks instigated learners to communicate freely applying the target language. The findings of the current study support the earlier research of (Cameron, 2001, Haastrup, 1991, Hamzah, Kafipour, \& Abdullah, 2009, Mondria \& Witde-Boer, 1991, Nation, 2001, Wang, Thomas, Inzana, \& Primicerio, 1993), which accentuated that the acquisition of diction is an accumulative process and that it should be on purpose and instructed, achieved, and recycled and showed that training in vocabulary strongly helps English language learning the basic skills of reading, writing, speaking and listening. Learning vocabulary subsequently improves students' English learning (Cameron, 2001). The outcomes of this research are also in coordination with some research done by (e.g. Al Jarf, 2007, Catalan, 2003, Fan, 2003, McCarthy, 1988, Nassaji, 2004, 2014).

Regarding the first investigation assumption outcomes which indicated that discrepancies would be recognized between the tools of the experimental group and the tools of the control group on the diction post-test and the achievement of word tactics survey and its subscales, which verified the truthfulness of the first assumption, the tools of the experimental group was better than the control one. Such an outcome essler \& Snow, 2005, Nation, 2001,) which confirmed that increasing of vocabulary by student learners cannot grow spontaneously but must be done through a training program. In addition, Al Batina, Al Rashedan, Al Sabila, and Al Khatita (2005) mentioned that there are some reasons that make a student unable to read the new vocabulary words if he has no specified strategy to follow, and if he does not know how to make a connection between phonemes and their meanings Furthermore it is difficult for them to read the word by using its phonemes or its segments. Accordingly, vocabulary leaning strategies programs are a necessity for EFL students to develop and increase their vocabulary.

With regard to the other assumption, the outcomes demonstrated that there exist notable discrepancies between the mean grades of the pre- and post-test for the experimental group on the vocabulary questionnaire strategies and its factors in favor of the post-test. It also depicts that there exist important discrepancies between the pre- and post-test for the experimental group on the vocabulary test score in favor of the post-test. This outcome is also in coordination with many investigations that showed the significance of the role of diction acquisitions tactics in word instruction and acquisition and are familiar with the requirement for helping students achieve the tactics necessary to achieve words on their own. (e.g. Nassaji, 2004, 2014, Schmitt, 2000, Vasu and Dhanavel, 2012, 2015). It also concurs with the study of Oxford and Scarcella (1994) that support the providing of systematic word teaching to allow learners to master specific strategies for the use of acquiring vocabulary words, and even continuing outside the classroom. This study also agrees with the study of (Saengpakdeejit, 2014) who said that through the application of word learning tactics, students can be capable of instructing the potential of their influence in their English language acquisition. In one very real sense, it is important to be aware of the foundations of word learning tactics and how learners can perform the tactics most influentially.

Accordingly, it is vital for the instructors to realize the specific diction acquisition needs of their students in order to effectively change the focus from what to teach to how to teach vocabulary in the classroom. In conclusion, there have been several studies which have indicated that students apply tactics to learn diction, though they may not be specifically aware of them (Vasu and Dhanavel, 2012, 2015). 


\section{Conclusion}

In short, the current research indicated that word acquisitions programme that based on diction learning tactics help word size of the students. Word acquisition tactics showed an indirect contribution. Such tactics encompass three most used used tactics belong to metacognitive, cognitive, memory and activation strategies. Word should be actively instructed, achieved, recycled and when possible, patched to the learners' requirements and purposes. Being exposed to the word should happen in various contexts and learners need to manipulate the diction in both receptive and productive tasks.

The instructors must instruct the students how to apply such tactics whenever required and attempt to involve such tactics in class tasks, homework, etc, so as to force the students to learn these tactics. Oxford (2001) asserted that making the students familiar with the tactics they apply in acquisition is one of the methods to improve their acquisition. As they are familiar with the tactics that help them to achieve better, they are instigated to apply them more in their acquisition.

\subsection{Recommendation}

If there is adequate time to be spent practicing and involving in meaningful tasks in the courses applying these memorized words, students can have an enhanced opportunity of understanding them and being capable of applying them influentially. Select myriads of word teaching methods that perform your instruction style and textbook, and give your learners the tactics they require to learn their word.

\subsection{Limitations of the study}

First limitation, since the research concentrates on only 123 EFL Saudi female students out of the hundreds of EFL students in classroom all across Taif University, this is the primary restriction of this study. Second, the learners in the present study Arabic learners in Saudi Arabia, therefore it is hard to determine whether the outcomes achieved from the current research can be generalized to Arabic language learners in other countries.

\section{References}

Ahmed, M. (1989). Vocabulary learning strategies. In P. Meara (Ed.), British studies in applied linguistics, 4, Beyond words (pp. 3-14). London: British Association of Applied Linguistics/Center for Language Teaching.

Akkakoson, S. (2012) Raising Strategic Awareness of Thai EFL Students of Science and Technology Disciplines through Metacognitive Strategy Training. The Southeast Asian Journal of English Language Studies, 18(4): 35-47.

Alaam, S. (2011). Educational and Psychological tests and Measurements, 2nd edition. Amman, Dar Al Fikr.

Al-Jarf, R. (2007). Teaching Vocabulary to EFL College Students Online. CALL-EJ Online, 8, 2. http://callej.org/journal/8-2/al-jarf.html

Asgari, A. \& Mustapha, G. (2011). The Type of Vocabulary Learning Strategies Used by ESL Students in University Putra Malaysia. English Language Teaching, 4 ( 2), 86-90. doi:10.5539/elt.v4n2p84

August, D., Carlo, M., Dressler, C. \& Snow, C. (2005). The critical role of vocabulary development for English language learners. Learning Disabilities Research and Practice, 20, 1, $50-57$.

Bastanfar, A. (2010). A Study of the Extent to Which VLS Research Informs Local Course books in Iran, International Education Studies, 3(3), 158- 166.

Brown, C. \& Payne, M. E. (1994). Five essential steps of processes in vocabulary Learning. Paper presented at the TESOL Convention, Baltimore, Md.

Burke, J. (2004). Learning the language of academic study. Voices from the Middle, 11(4), 37-42.

Cameron, L. (2001). Teaching Languages to Children. Cambridge: Cambridge University Press.

Catalan, R. (2003). Sex differences in L2 vocabulary learning strategies. International Journal of Applied Linguistics, 13(1), 54-77.

Coady, J. (1997). L2 vocabulary acquisition: A synthesis of research. In J. Coady\& Th. Huckin (Eds.), Second language vocabulary acquisition: A rationale for pedagogy (pp.273-91). Cambridge: Cambridge University Press.

Cunningsworth, A. (1995). Choosing your course book. Oxford: Heinemann.

Dhanavel, S. P. (2012). English Language Teaching in India: The Shifting Paradigms. New Delhi:Tata McGraw-Hill Ltd.

Fan, Y. M. (2003). Frequency of use, perceived usefulness, and actual usefulness of second language vocabulary strategies: A study of Hong Kong learners. The Modern Language Journal, 87(2), 222-241.

Gu, Y., \& Johnson, R. K. (1996). Vocabulary learning strategies and language learning outcomes. Language Learning 46(4), $643-79$.

Hamzah, M. S. Kafipour, R. \& Abdullah, S. K. (2009).Vocabulary Learning Strategies of Iranian Undergraduate EFL Students and its Relation to their Vocabulary Size. European Journal of Social Sciences, 11(1), 39-50. 
Hanson, S \& Padua, J. (2015). Teaching Vocabulary Explicitly. U.S. Department of Education's Institute of Education Sciences (IES), Pacific Resources for Education and Learning.

Hatch, E., \& Brown, C. (1995). Vocabulary, semantics, and language education. Cambridge: Cambridge University Press.

Hu, H. M., \& Nassaji, H. (2014). Lexical inferencing strategies: The case of successful versus less successful inferences'. System, 45, 27-38.

Kaya, J. \& Charkova,K. (2014). The Most and Least Frequent Vocabulary Learning Strategies of High School English Language Learners. International Journal of English Language Education, 2(2), 122-141.

Lawson, M. J. \& Hogben, D. (1996). The vocabulary-learning strategies of foreign-Language students. Language Learning, 46(1), 101-135.

Lehr, F., Osborn, J., \& Hiebert, E. (2004). Focus on vocabulary. Honolulu, HI: Pacific Resources for Education and Learning.

Lightbown, P. \& Spada,N. (1999). How languages are learned. Oxford,UK:Oxford University Press.

Lin, L. (2001). Taiwanese children's EFL vocabulary learning strategies. Unpublished MA Thesis, Chin-Hwa University, Taipei, Taiwan.

Little1, A. and Kobayashi, K. (2015). Vocabulary Learning Strategies of Japanese Life Science Students. TESOL Journal, 6 (1), 81-111.

Lotfi, G. (2007). Learning vocabulary in EFL contexts through vocabulary learning strategies. Novitas-ROYAL, 1(2), 84-91.

Maiguashca, R. U. (1993). Teaching and learning vocabulary in a second language: Past, present, and future directions. Canadian Modern Language Review, 50, 83-100.

McCarthy, M. (1988).Vocabulary and Language Teaching. New York: Longman.

Meara, P. (1982). Vocabulary acquisition: A neglected aspect of language learning. In V. Kinsella (Ed.), Surveys I: Eight state-of-the-art articles on key areas in language teaching (pp. 100-126). Cambridge: Cambridge University Press.

Meara, P. (1995). The importance of an early emphasis on L2 vocabulary. JALT, 19, 8-11. Retrieved February, 2010 from http://www.jalt-publications.org/tlt/files/95/feb/meara.html

Milton, J. (2009). Measuring second language vocabulary acquisition. Bristol, UK: Multilingual Matters.

Monash College Pty Ltd (2015). English Book 1, units 1 to7, (4th ed). Commonwealth of Australia

Morad, S. A. (2000). Statistical Methods for the Social, Educational and Psychological Sciences. Cairo: El-Anglo ELMasriya.

Morin, R. \& Goebel, J. (2001).Basic vocabulary instruction teaching strategies or word? Foreign Language Annals, 34 (1), -16 .

Nassaji, H. (2004). The relationship between depth of vocabulary knowledge and L2 learners' lexical inferencing strategy use and success. Canadian Modern Language Review, 61, 1, 107-134.

Nation, I. S. P. (2001). Learning Vocabulary in Another Language. Cambridge: Cambridge University Press.

Oxford, R. \& Nyikos, M. (1989).Variables Affecting Choice of Language Learning Strategies by University Students. The Modern Language Journal, 79(3), 291-300.

Oxford, R. \& Scarcella, R.C. (1994). Second language vocabulary learning among adults: state of the art in vocabulary instruction. System, 22(2), 231-243.

Oxford, R. (2001). Language learning strategies. In R. Carter \& D. Nunan, The Cambridge Guide to Teaching English to Speakers of Other Languages. (pp. 166-171). Cambridge: Cambridge University Press.

Peters, E \& Dixon, R. (1987). Special focus: effective instruction in reading. strategies for vocabulary instruction. Teaching Exceptional Children, 19(2), 61-63.

Ranalli, J. (2003). The Treatment of Key Vocabulary Learning Strategies in Current ELT Course books: Repetition, Resource Use, Recording. Unpublished MA thesis.

Saengpakdeejit, R. (2014). Strategies for Dealing with Vocabulary Learning Problems by Thai University Students. Journal of Social Sciences, Humanities, and Arts, 14(1), 147-167.

Samian, S. H. \& \& Tavakoli, M. ( 2012). The Relationship between Iranian EFL Learners Rote Learning Strategy Use and Their Level of Proficiency. Journal of Language Teaching and Research, 3(4), 625-631,

Sanaoui, R. (1995). Adult learners' approaches to learning vocabulary in second languages. Modern Language Journal, 79(1), 15-28.

Scharle, A. \& Szabó, A. (2000).Learner Autonomy. A Guide to Developing Learner Responsibility. Cambridge: Cambridge University Press. 
Schmitt, N. (1997). Vocabulary learning strategies. In N. Schmitt \& M. McCarthy (Eds.), Vocabulary: Description, acquisition and pedagogy. Cambridge: Cambridge University Press.

Schmitt, N. (2000). Vocabulary in language teaching. New York, NY: Cambridge University Press.

Smith, V. L. (1983). Vocabulary building for university-bound ESL students. ERIC Document Reproduction Service No. ED230037.

Sokmen, A. (1997). Current trends in teaching second language vocabulary. In N. Schmitt \& M. McCarthy (eds.), Vocabulary: Description, acquisition and pedagogy. (pp.237-257). Cambridge: Cambridge University Press.

Somsai, S. and Intaraprasert, C. (2011) Strategies for Coping with Faceto- Face Oral Communication Problems Employed by Thai University Students Majoring in English. GEMA Online ${ }^{\mathrm{TM}}$ Journal of Language Studies 11(3): 8396.

Stoffer, I. (1995). University foreign language students' choice of vocabulary learning strategies as related to individual difference variables. Unpublished Doctoral Dissertation, University of Alabama.

Vasu, S. and Dhanavel, S. P. (2015). Exploring the Vocabulary Learning Strategy Use of Teachers in Their Vocabulary Instruction. Croatian Journal of Education, 18(1)103-135.

\section{Appendices}

\section{Appendix A: Schmitt questionnaire}

Dear student:

I. Discovery dimension

1. Determination strategies (DET) used by individual when faced with discovering a new word's meaning without recourse to another person`s expertise

2. Social strategies (SOC) use interaction with other people to improve language learning

II. Consolidation strategies:

1. Social strategies(SOC) have group work to learn or practice vocabulary .

2. Memory strategies (MEM) relate new material to existing knowledge

3. Cognitive strategies (COG) exhibit the common function of manipulation or translation of the target language by the learner.

4. Metacognive strategies (MET) involve a conscious overview of the learning process and making decision about planning, mentioning or evaluating the best ways to study.

\begin{tabular}{|c|c|c|c|c|c|c|}
\hline No. & Items & $\begin{array}{l}\text { Strongly } \\
\text { disagree }\end{array}$ & Disagree & Neutral & Agree & $\begin{array}{l}\text { Strongly } \\
\text { agree }\end{array}$ \\
\hline & Determination strategies & & & & & \\
\hline 1 & Analyze part of the speech & 1 & 2 & 3 & 4 & 5 \\
\hline 2 & Analyze affixes and root & 1 & 2 & 3 & 4 & 5 \\
\hline 3 & Check for L1 cognate & 1 & 2 & 3 & 4 & 5 \\
\hline 4 & $\begin{array}{l}\text { Analyze any available pictures or } \\
\text { gestures }\end{array}$ & 1 & 2 & 3 & 4 & 5 \\
\hline 5 & Guess from textual context & 1 & 2 & 3 & 4 & 5 \\
\hline 6 & Bilingual dictionary & 1 & 2 & 3 & 4 & 5 \\
\hline 7 & Monolingual dictionaries & 1 & 2 & 3 & 4 & 5 \\
\hline 8 & Word lists & 1 & 2 & 3 & 4 & 5 \\
\hline \multirow[t]{2}{*}{9} & Flash cards & 1 & 2 & 3 & 4 & 5 \\
\hline & Social strategies & & & & & \\
\hline 10 & Ask teacher for L1 translation & 1 & 2 & 3 & 4 & 5 \\
\hline 11 & $\begin{array}{l}\text { Ask teacher for paraphrase or synonym } \\
\text { of new word }\end{array}$ & 1 & 2 & 3 & 4 & 5 \\
\hline 12 & $\begin{array}{l}\text { Ask teacher for a sentence including the } \\
\text { new word }\end{array}$ & 1 & 2 & 3 & 4 & 5 \\
\hline \multirow[t]{2}{*}{13} & Ask classmates for meaning & 1 & 2 & 3 & 4 & 5 \\
\hline & Consolidation Strategies & 1 & 2 & 3 & 4 & 5 \\
\hline 14 & Study and practice meaning in a group & 1 & 2 & 3 & 4 & 5 \\
\hline 15 & $\begin{array}{l}\text { Teacher checked students' flash cards } \\
\text { word lists for accuracy }\end{array}$ & 1 & 2 & 3 & 4 & 5 \\
\hline 16 & Interact with native-speakers. & 1 & 2 & 3 & 4 & 5 \\
\hline
\end{tabular}


ALLS 8(3):113-125, 2017

\begin{tabular}{|c|c|c|c|c|c|c|}
\hline & Memory strategies & 1 & 2 & 3 & 4 & 5 \\
\hline 17 & $\begin{array}{l}\text { Study word with a pictorial } \\
\text { representation of its meaning. }\end{array}$ & 1 & 2 & 3 & 4 & 5 \\
\hline 18 & Image word`s meaning & 1 & 2 & 3 & 4 & 5 \\
\hline 19 & Connect word to a personal experience & 1 & 2 & 3 & 4 & 5 \\
\hline 20 & Associate the word with its coordinates & 1 & 2 & 3 & 4 & 5 \\
\hline 21 & $\begin{array}{l}\text { Connect the word with its synonyms and } \\
\text { antonyms }\end{array}$ & 1 & 2 & 3 & 4 & 5 \\
\hline 22 & Use semantic maps & 1 & 2 & 3 & 4 & 5 \\
\hline 23 & Use scales for gradable adjectives & 1 & 2 & 3 & 4 & 5 \\
\hline 24 & Peg Method & 1 & 2 & 3 & 4 & 5 \\
\hline 25 & Loci Method & 1 & 2 & 3 & 4 & 5 \\
\hline 26 & Group words together to study them & 1 & 2 & 3 & 4 & 5 \\
\hline 27 & Group words together spatially on a page & 1 & 2 & 3 & 4 & 5 \\
\hline 28 & Use new word in sentences & 1 & 2 & 3 & 4 & 5 \\
\hline 29 & Group words together within a storyline & 1 & 2 & 3 & 4 & 5 \\
\hline 30 & Study the spelling of a word & 1 & 2 & 3 & 4 & 5 \\
\hline 31 & Study the sound of a word & 1 & 2 & 3 & 4 & 5 \\
\hline 32 & Say new word aloud when studying & 1 & 2 & 3 & 4 & 5 \\
\hline 33 & Image word form & 1 & 2 & 3 & 4 & 5 \\
\hline 34 & Underline initial letter of the word & 1 & 2 & 3 & 4 & 5 \\
\hline 35 & Configuration & 1 & 2 & 3 & 4 & 5 \\
\hline 36 & Use keyword method & 1 & 2 & 3 & 4 & 5 \\
\hline 37 & Affixes and roots & 1 & 2 & 3 & 4 & 5 \\
\hline 38 & Part of speech & 1 & 2 & 3 & 4 & 5 \\
\hline 39 & Paraphrase the word's meaning & 1 & 2 & 3 & 4 & 5 \\
\hline 40 & Use cognates in study & 1 & 2 & 3 & 4 & 5 \\
\hline 41 & Learn the words of idiom together & 1 & 2 & 3 & 4 & 5 \\
\hline 42 & $\begin{array}{l}\text { Use physical action when learning a } \\
\text { word }\end{array}$ & 1 & 2 & 3 & 4 & 5 \\
\hline 43 & Use semantic feature grids & 1 & 2 & 3 & 4 & 5 \\
\hline & Cognitive strategies & & & & & \\
\hline 44 & Verbal repletion & 1 & 2 & 3 & 4 & 5 \\
\hline 45 & Written repetition & 1 & 2 & 3 & 4 & 5 \\
\hline 46 & Word lists & 1 & 2 & 3 & 4 & 5 \\
\hline 47 & Flash cards & 1 & 2 & 3 & 4 & 5 \\
\hline 48 & Take notes in class & 1 & 2 & 3 & 4 & 5 \\
\hline 49 & $\begin{array}{l}\text { Use the vocabulary section in your text } \\
\text { book }\end{array}$ & 1 & 2 & 3 & 4 & 5 \\
\hline 50 & Listen to tape of word lists & 1 & 2 & 3 & 4 & 5 \\
\hline 51 & Put English labels on physical & 1 & 2 & 3 & 4 & 5 \\
\hline \multirow[t]{2}{*}{52} & Keep a vocabulary note book & 1 & 2 & 3 & 4 & 5 \\
\hline & Metacognitive strategies & & & & & \\
\hline 53 & $\begin{array}{l}\text { Use-English Language media (songs, } \\
\text { movies, newscast,...etc.) }\end{array}$ & 1 & 2 & 3 & 4 & 5 \\
\hline 54 & Testing oneself with word tests & 1 & 2 & 3 & 4 & 5 \\
\hline 55 & Use spaced word practice & 1 & 2 & 3 & 4 & 5 \\
\hline
\end{tabular}

Thanks for your help

The researchers 